\title{
Consumer Legal Protection: Building Legal Awareness in the Age of Globalization
}

\author{
Josef Purwadi Setiodjati ${ }^{1.4}$, Jamal Wiwoho ${ }^{2}$, Suraji ${ }^{3}$ \\ ${ }^{1.2 .3}$ Faculty of Law, Universitas Sebelas Maret, Surakarta, Indonesia \\ ${ }^{4}$ Faculty of Law, Universitas Slamet Riyadi, Indonesia \\ Josef197089@gmail.com
}

\begin{abstract}
Consumers are one of the backbones of the economy. Without consumers, the production sector cannot run smoothly. The large population of Indonesia ensures that the country has large consumption power. However, whether this potential benefit followed by the protection of consumer rights is an important question. This is significant to address because consumers are considered having a weaker bargaining position and therefore vulnerable to being exploited. This article aims to show how the legal protection for consumer. This article applies a normative approach. Data are gathered from a review of consumer protection laws. This study shows that based on legal policies, the state tries to protect consumer rights in order to foster a good transaction climate. This protection of consumer rights is reflected in the rule of law that emphasizes consumer rights, the obligations of business actors, and prohibitions for business actors from actions that can harm consumers. However, consumer protection is acceptable to be normative and must also be built based on the consumer own legal awareness.
\end{abstract}

Keywords- Consumer Protection Law, Legal Awareness, Consumer rights.

\section{INTRODUCTION}

Globalization has accelerated the rate at which businesses compete in a variety of production sectors. Indonesia, as a developing country, cannot avoid the various consequences of this progress, particularly in terms of trade transactions. Trade transactions take place not only on a local level, but also on a global scale. There is no requirement for business actors and consumers to be acquainted. A transaction is entirely focused on the goods being traded. Numerous questions arise from this, including whether the goods sold correspond to the goods received by the buyer [1]. What if the business actor's promise of a bang is not fulfilled?

Consumers are defined as "anyone who uses goods and/or services available in the community for the benefit of their own, their families, other people, or other living creatures and not for trading purposes." Thus, a consumer is defined in this article as anyone who uses goods and/or services available in the community for their own, their families', other people, and other living creatures' benefit, rather than for trading. Consumers and business actors frequently have unequal relationships [2]. Consumers frequently suffer losses during the exchange of goods and services in society as a result of a lack of information or incorrect information about the purchased product or service [3] [4].

Consumers frequently experience loss when they do not receive goods in accordance with the information provided by business actors. As the weaker party, consumers frequently submit and do not attempt to defend their rights that have been violated. This is becoming increasingly prevalent in the age of electronic commerce, in which trade is not conducted directly between sellers and buyers [5]. Consumers obtain information about products or services solely from the product descriptions listed on the application layer or on online trading platforms. This is, of course, a risk for consumers [6].

The low level of awareness of consumer law at the local level accentuates the difficulties consumers face in this era of globalization. Foreign goods and services enter and exit the country rapidly. As a result, it is critical to make efforts to increase consumer legal awareness in order to achieve product legal awareness.

\section{FINDINGS AND DISCUSSION}

\section{Consumer Protection Legal Policy}

Consumer protection is defined as "all efforts directed toward ensuring legal certainty for the benefit of consumers." The substance of consumer protection law policy must be thoroughly understood by the public in order for them to understand their rights and the legal process for asserting consumer rights violations.

Consumer rights are regulated by the Consumer Protection Law No. 8 of 1999. (in the future referred to as UUPK). Consumer rights are enshrined in UUPK Article 4. These rights are an integral part of the responsibilities of business actors. This means that business actors are required and accountable to exercise all of these rights concurrently in each transaction or use of a product or service. Article 17 of the UUPK also prohibits business actors from deceptively advertising the quality, quantity, materials, uses, and prices of goods and/or services, as well as the timeliness with which goods and/or services are delivered [7]. Additionally, it is prohibited for business actors to defraud the guarantee of goods and/or services. Additionally, business actors are prohibited from posting false, inaccurate, or misleading information about their products and/or services. These prohibitions are part 
of a broader legal strategy aimed at safeguarding consumer rights [8].

Apart from being regulated by the consumer protection law, Indonesia also establishes a legal framework for the protection of all electronic transactions. This arrangement is outlined in the 2008 Information and Electronic Transactions Law (UU ITE) [9]. Article 9 of the ITE Law requires business actors who offer products via Electronic Systems to provide complete and accurate information about contract terms, producers, and offered products. In this case, the information created by business actors to attract consumers must correspond to the products offered in order to avoid confusing consumers [10]. The obligations of business actors demonstrate the state's desire to protect consumers in all transactions of goods and services through consumer protection laws. Additionally, the following section will discuss how consumers' fundamental rights are protected by law [11].

\section{Consumer Rights}

As mentioned previously, consumers are protected by law as citizens in a relatively vulnerable position. The protection at issue is the legal recognition of consumer rights. Consumers' legal rights and obligations are summarized in the following table 1 .

According to the aforementioned legal standards, consumer protection appears to begin with the obligation of business actors to enter into transactions in good faith. Only after this goodwill is established is the right to information emphasized. This is in accordance with Article 4 letter c of the UUPK, as well as Article 7 letter b of the UUPK, which requires business actors to provide trustworthy, transparent, and honest information about the condition of the goods being traded [12]. Consumers' right to this information serves as the starting point for determining whether to proceed with the transaction or not. As a result, consumer protection law places a premium on the right to information about goods and services. In other words, this right to information serves as the foundation for the implementation of additional rights, such as the right to choose a product, which is followed by the right to a just agreement. Consumers will have difficulty determining other rights if information rights are not protected [13].

The table above demonstrates the reciprocal relationship between consumer rights and the obligations of business actors. Consumers have rights, businesses have responsibilities, and vice versa. Along with emphasizing consumer rights and business actors' obligations, the law also emphasizes business actors' prohibitions. These prohibitions demonstrate how the law intends to prevent consumer rights violations. The following table summarizes several prohibitions applicable to business actors. See table 2 .

These arrangements are predicated on the following considerations: (1) the development of the national economy in the age of globalization is aimed at fostering business growth so that it can produce a variety of goods and/or services with technological content that can improve the general public's welfare while also ensuring consumer certainty over goods and/or services obtained through trade; (2) the increasing globalization of the national market must continue to improve people's welfare and ensure the quality, quantity, and security of the goods and/or services obtained; and (3) to enhance consumers' dignity, it is necessary to increase their awareness, knowledge, concern, ability, and independence in protecting themselves, as well as to foster an attitude of responsible business actors [14].

By recognizing consumer rights and imposing obligations and prohibitions on business actors, the state can be considered to provide legal protection for consumers through its legal policies [15]. While this law has protected consumers rigidly and precisely, this does not mean that consumer protection has been optimal. These protection standards are contingent upon not only the implementing standards - which come before them but also on the level of public awareness. While law as a norm is purely substantive, the effectiveness of a norm is also contingent on the functioning of the legal culture, in this case, the legal awareness that grows and develops in society [16].

\section{Consumer Legal Awareness}

Legal awareness refers to human conceptions of law, either existing law (ius constitutum) or law that is expected to exist (ius conatituendum). Legal awareness is an awareness of what we should or should not do, particularly to others. Paul Scholten defines legal awareness as "every human being's awareness of what the law is or should be." Awareness is a subcategory of the human psyche that denotes what should and should not be done.

As a result of this explanation, it is possible to deduce that legal awareness serves as a bridge between the law of behavior and the law of society. Legal awareness encompasses cognitive and emotional dimensions that are frequently cited as a determinant of community order [17]. This means that if a person possesses legal awareness, he or she is capable of distinguishing between permissible and prohibited actions. Legal awareness is determined by four indicators: legal knowledge and comprehension; legal stance; and legal behavior patterns. Each indicator denotes a different level of legal awareness, from the most basic to the most advanced. Consumer legal awareness of a product can be determined by these indicators, which include consumer knowledge, understanding, attitudes, and behavior. Consumer legal awareness, by this definition, is the consumer's understanding of their legal rights as consumers, as guaranteed by laws and regulations [4].

According to the explanation above, legal awareness begins with legal knowledge. Legal knowledge is necessary for an individual to comprehend the law. If one possesses legal knowledge, then one develops legal attitudes and behaviors that reflect legal awareness. Consumers' legal awareness of a product is influenced by 
educational, economic, religious, and sociocultural factors. Increasing public legal awareness can be accomplished through education, which teaches consumers their rights and responsibilities. Legal counseling and ongoing consumer protection law campaigns can be used to educate in this context [18].

\section{IV.CONCLUSION}

Efforts to maintain the dignity of consumers need to be supported by increasing consumer awareness, knowledge, care, ability, and independence to protect themselves and foster responsible business actors' attitudes. Based on the arrangement above, it appears that the rights and obligations of business actors are reciprocal with the rights and obligations of consumers. This means that the rights of consumers are obligations that business actors must fulfill. Likewise, consumer obligations are rights that business actors will receive. In terms of protecting consumer rights, the Consumer Protection Law requires business actors to conduct business activities based on good faith. This law also requires a conducive business climate without unfair competition between business actors. Based on the discussion above, it can be concluded that normatively consumer rights have been protected by law. However, this legal protection needs to be strengthened by consumers themselves through increasing legal awareness. Building legal awareness is the most effective way to protect consumer rights.

\section{REFERENCES}

[1] O. Karlina, "Juridical analysis on consumer protection against personal data theft from ecommerce platforms in Indonesia." Universitas Pelita Harapan, 2020.

[2] R. Res, "Implementation of Parate Executie Object of Liability Juridical Overview of Mortgage," vol. 1, no. 1, pp. 42-53, 2021.

[3] G. T. Sekotibo, "The Strength of Evidence (Certificate) in Land Rights Disputes According to Government Regulation No. 24 of 1997 Concerning Land Registration," J. Hum. Rights, Cult. Leg. Syst., vol. 1, no. 2, pp. 120-130, 2021, doi: 10.53955/jhcls.v1i2.12.

[4] R. Arifin, J. A. Kambuno, W. Waspiah, and D. Latifiani, "Protecting the Consumer Rights in the Digital Economic Era: Future Challenges in Indonesia," Jambura Law Rev., vol. 3, pp. 135-160, 2021.

[5] M. Jamil, "Fiduciary Security Arrangements and Issues in Indonesia," J. Hum. Rights, Cult. Leg. Syst., vol. 1, no. 2, pp. 109-119, 2021, doi: 10.53955/jhcls.v1i2.1.

[6] A. B. Kuncoro, I. G. A. K. R. Handayani, Y. T. Muryanto, and L. Karjoko, "Consumer Protection Based on Justice in Order to Advance State Administration Systems in Indonesia," 2019, doi: 10.2991/icglow-19.2019.22.
[7] A. A. Herman and M. J. Hayat, "Management of High Secondary Education After Regional Government Law," J. Hum. Rights, Cult. Leg. Syst., vol. 1, no. 2, pp. 395-396, 2021, doi: 10.53955/jhcls.v1i2.11.

[8] S. S. A. Yusoff, S. M. Isa, and A. A. Aziz, "Legal approaches to unfair consumer terms in Malaysia, Indonesia and Thailand," Pertanika J. Soc. Sci. Humanit., vol. 20, no. SPEC. ISS., pp. 43-55, 2012.

[9] S. Syahlan, "Effective and Efficient Synchronization in Harmonization of Regulations Indonesia," $J$. Hum. Rights, Cult. Leg. Syst., vol. 1, no. 1, pp. 2807-2812, 2021, doi: 10.53955/jhcls.v1i1.7.

[10] A. Ma'ruf, “Application of Timber Legality Verification System (SVLK) Policy as Ecolabel Implementation in the Indonesian Timber Industry," J. Hum. Rights, Cult. Leg. Syst., vol. 1, no. 2, pp. 92-99, 2021, doi: 10.53955/jhcls.v1i2.10.

[11] A. S. Hidayat, F. S. Alam, and M. I. Helmi, "Consumer protection on peer to peer lending financial technology in Indonesia," Int. J. Sci. Technol. Res., vol. 9, no. 1, pp. 4069-4072, 2020.

[12] S. D. Baranyanan, "Simplification of Law Regulations in Copyright Criminal Act Settlement," J. Hum. Rights, Cult. Leg. Syst., vol. 1, no. 2, pp. 80-91, 2021, doi: 10.53955/jhcls.v1i2.9.

[13] S. D. Rosadi and Z. Tahira, "Consumer Protection in Digital Economy Era: Law in Indonesia," Yust. J. Huk., vol. 7, no. 1, p. 81, 2018, doi: 10.20961/yustisia.v0i0.20144.

[14] A. K. Jaelani, U. S. Maret, R. D. Luthviati, C. Registration, S. Program, and U. S. Maret, "The Crime Of Damage After the Constitutional Court 's Decision Number 76 / PUU-XV / 2017," vol. 1, no. 1, pp. 31-41, 2021.

[15] F. U. Najicha, "Oil and Natural Gas Management Policy in Realizing Equal Energy in Indonesia," $J$. Hum. Rights, Cult. Leg. Syst., vol. 1, no. 2, pp. 7179, 2021, doi: 10.53955/jhcls.v1i2.8.

[16] F. Sugianto, E. Sukardi, and T. Michael, "Comparison of Legal Consumer Protection Systems in E-Commerce Transactions To Support Digital Economic Growth in Indonesia," Dalat Univ. J. Sci., vol. 12, no. 1, p. 39, 2021, doi: 10.37569/dalatuniversity.12.1.814(2022).

[17] I. Iswantoro, "Strategy and Management of Dispute Resolution, Land Conflicts at the Land Office of Sleman Regency," J. Hum. Rights, Cult. Leg. Syst., vol. 1, no. 1, pp. 2807-2812, 2021, doi: 10.53955/jhcls.v1i1.3.

[18] A. Ma'ruf, "Legal Aspects of Environment in Indonesia: an Efforts to Prevent Environmental Damage and Pollution," vol. 1, no. 1, pp. 18-30, 2021. 